\title{
Shoot proliferation, leaf anatomy and pigment content of Eugenia dysenterica growing in conventional and natural ventilation systems ${ }^{1}$
}

\author{
Andreia Alves da Costa Silveira ${ }^{2}$ (D) Letícia Almeida Gonçalves ${ }^{3}$, Elienai Candida e Silva ${ }^{3}$, \\ Nauany da Silva Sales ${ }^{3}$, Lívia Cristina da Silva², Sérgio Tadeu Sibov ${ }^{3}$
}

10.1590/0034-737X201966050005

\begin{abstract}
Natural ventilation micropropagation systems differ from conventional systems by allowing gas exchange between the internal and external media of the culture flask. The objective of this work was to compare the conventional system of in vitro propagation of Eugenia dysenterica (Mart.) DC. with a natural ventilation system. For shooting, explants were inoculated into test tubes with conventional lids and natural ventilation lids (NV), and WPM medium supplemented with four concentrations levels of 6-benzilaminopurine (BAP). The position of explants in each plant was considered by identifying buds as more proximate to the root, or to the apex, or in an intermediate position. Plant growth in the natural ventilation system was superior to that in the conventional system, with a $448.53 \%$ increase in leaf number, $85.64 \%$ increase in chlorophyll $a$ levels and $74.90 \%$ increase in chlorophyll $b$ levels. Plants with intermediate buds exhibited better results. Foliar anatomical analysis revealed abnormalities in leaves grown in the conventional system such as "giant" stomata, which remain always open. Our results indicate that the use of natural ventilation improves the water loss regulation capacity in micropropagated $E$. dysenterica plants and may favor plants survival and growth after transference to the natural environment.
\end{abstract}

Keywords: cagaiteira; in vitro growth system; natural ventilation; plant tissue culture.

\section{INTRODUCTION}

Eugenia dysenterica (Mart.) DC. (popularly known as cagaiteira) is a fruit tree species that occurs in Cerrado regions (Brazilian savanna) and has the potential for economic use. Exploited extractively, its main use is in the commercialization of its by-products such as ice cream, sweets and juices (da Silva et al., 2017). The species also possesses medicinal properties, being used as an antioxidant (Takao et al., 2015); a laxative, from fruit consumption (Silva et al., 2015); and antidiarrheal, from leaf extract consumption (Galheigo et al., 2016), among others (Lima et al., 2010; Lima et al., 2011; Souza et al. 2012).
The period of fruiting of $E$. dysenterica coincides with the beginning of the first rains after drought in Brazilian savannah regions. However, the seed viability period is considered short (approximately 50 days), which characterizes the seed recalcitrance. (Farias Neto et al., 1991; Andrade et al., 2003). Thus, the conventional production of seedlings of this species at any time of the year becomes infeasible, and requires alternative methods of vegetative propagation, such as micropropagation.

Micropropagation is a set of techniques that provides large-scale seedling production. If properly applied, micropropagation results in uniform individuals very similar to those from seeds and is up to a thousand times more productive than conventional propagation techniques.

\footnotetext{
Submitted on June 17th, 2019 and accepted on September $9^{\text {th }}, 2019$.

${ }^{1}$ This work is part of the first author's Master Dissertation.

${ }^{2}$ Universidade Federal de Goiás, Escola de agronomia, Goiânia, Goiás, Brazil. andreiaac2@gmail.com; liviacristy@gmail.com

${ }^{3}$ Universidade Federal de Goiás, Instituto de Ciências Biológicas, Goiânia, Goiás, Brazil. leticia.icb.ufg@ gmail.com; elienaibio@gmail.com; nauanyssales@gmail.com; stsibov@gmail.com *Corresponding author: andreiaac2@gmail.com
} 
However, the application of conventional propagation to woody plants remains limited by the high cost of production, which is largely due to relatively low growth rates, significant losses due to contamination, lack of rooting and low percentages of in vitro plant survival after transfer to ex vitro (Kozai \& Kubota 2001).

Thus, in addition to developing micropropagation methods, it is also necessary to improve these methods as a way to guarantee the propagation of plant material at any time of the year. Studies on propagation techniques for the native wood species of Brazil (including $E$. dysenterica) are still scarce (Dias et al., 2012). This kind of propagation is a way to overcome difficulties in seed propagation and the cloning of genotypes of native forest species, thus making it possible to use the species for commercial purposes, as well as to help the conservation of forest genetic resources (Hawkes et al., 2012). Considering the unbridled deforestation of the Cerrado domain (Brazilian savanna) (Brandão et al., 2017), it is necessary to develop in vitro propagation protocols for this species in order to obtain in vitro conservation protocols in the future.

In the "heterotrophic" conventional micropropagation system, seedlings are stored in sealed flasks with low light intensity and no internal ventilation. Plants grown under this regime have several morphological disorders caused by the high relative humidity and the accumulation of gases inside the flasks. These morphological disorders include anatomical changes such as deformed stomata. Studies describe that the reduction of gas exchange in the culture flask may cause stomatal abnormalities, which may compromise, the pigment content as well as stomatal conductance. (Monja-Mio et al., 2015; Gago et al., 2016). Other disorders related to the conventional system include: hyperhydricity, reduced leaves, premature death of explants and, consequently, high losses in acclimatization (Kozai \& Kubota, 2005; Hazarika, 2006). Different cultivation systems have been used to increase the seedling nutritional quality, and the reduction of losses of micropropagated plants. The use of pigment quantification to monitor photosynthetic performance in plants is widespread (Baker, 2008). In the natural ventilation system, gas exchange is added to the system, thus improving the transpiration rate and, consequently, nutrient absorption. It is also known that rates of photosynthesis can be increased and significantly promoted by increasing $\mathrm{CO}_{2}$ concentrations and by decreasing relative humidity in the culture vessel (Kozai \& Kubota, 2005; Saldanha et al., 2012). Considering that E. dysenterica has economic potential (Camilo et al., 2013), it is necessary to develop protocols for in vitro propagation of the species aiming at large-scale seedling production. It also becomes necessary that these seedlings have morphological and nutritional quality, and thus, the improvement of micropropagation techniques is necessary. This work had the objective of developing a shoot proliferation protocol for $E$. dysenterica, by comparing two in vitro growth conditions: a conventional and a natural ventilation system, and observing leaf anatomy and chlorophyll production.

\section{MATERIALS AND METHODS}

\section{Disinfection and germination}

E. dysenterica fruits were collected in October 2013 from the Coleção de Espécies Frutíferas do Cerrado of the Escola de Agronomia, da Universidade Federal de Goiás. Five hundred seeds were removed from the ripe fruits, washed and placed on absorbent paper for two days to eliminate excess moisture (Duarte, 2006). Seed coats were removed with the aid of a scalpel (Martinotto et al., 2007) and the seeds were washed with running water for 20 minutes.

For decontamination, the seeds were placed in a sterilized flask and placed in a laminar flow chamber, where they were immersed in $70 \%$ alcohol for one minute. The seeds were then placed in a sterile flask with $0.5 \%$ sodium hypochlorite solution of active chlorine for 20 minutes, after which they were passed through a triple wash in autoclaved distilled water. Once decontaminated, the seeds were inoculated into test tubes containing $20 \mathrm{ml}$ of WPM medium (Lloyd \& McCown, 1980) supplemented with 3\% sucrose $(\mathrm{p} / \mathrm{v})$ and $2.5 \%(\mathrm{p} / \mathrm{v})$ of Gelsan ${ }^{\circledR}$, and maintained in a growth room with a temperature of $25 \pm 1{ }^{\circ} \mathrm{C}$, luminosity of $42 \mu \mathrm{mol} . \mathrm{m}^{-2} . \mathrm{s}^{-1}$ and a photoperiod of $16 \mathrm{~h}$ light $/ 8 \mathrm{~h}$ dark for at least ninety days and/or until the plants reached at least $100 \mathrm{~mm}$ in height with at least three axillary buds.

\section{Shoot proliferation}

An experiment was performed with flasks with sealed lids (conventional system) and flasks with lids that allowed gas exchange with the external environment (natural ventilation system - NV). Each lid of the latter contained a $5.0 \mathrm{~mm}$ hole, that was covered with two layers of microporous tape and a layer of thread-sealing tape (PTFE tape). Lateral seals for both types of lids were made with two layers of PVC film (Saldanha et al., 2012).

Under aseptic conditions, axillary and apical buds ( 0.5 $\mathrm{mm}$ diameter) were sectioned and inoculated in WPM medium supplemented with $3 \%$ sucrose (w/v) and exposed to treatments of four concentrations of 6-benzylaminopurine (BAP) $[0.00 \mu \mathrm{M}$ (control); $4.44 \mu \mathrm{I} ; 11.10 \mu \mathrm{I}$; and 17.76 $\mu \mathrm{M}]$ with thirty-two replicates. The juvenility of the tissue within each concentration of BAP was considered, and the position of the buds relative to the root and caulinar apex of the mother plant was identified. In this sense, each of the following types of buds had eight replicates: 
1 - Axillary buds proximate to the root;

2 - Axillary buds intermediate between root and caulinar apex;

3 - Axillary buds more proximate to the caulinar apex;

4 - Apical bud.

The test tubes containing the explants were kept in a growth room under the same conditions of growth described previously for three months. The culture medium with the respective treatments was replaced every fortyfive days. The height of the largest shoot, the number of shoots and the number of leaves were evaluated. When evaluating the height of the largest shoot in axillary buds, the shoot was considered from the axillary bud to the insertion of the last leaf.

\section{Leaf anatomy analysis}

In order to evaluate the influence of the conventional and natural ventilation systems on the development of the plants, a study of leaf anatomy was carried out. Leaves from buds type 2 and 3 were used. The material was fixed in FAA [37-40\% formaldehyde, glacial acetic acid, and 70\% ethanol $(1: 1: 18, \mathrm{v} / \mathrm{v} / \mathrm{v})]$ and stored in $70 \%$ ethanol until processing. Part of this material was used for diaphanization (Johansen, 1940) and part for embedding in hydroxyethyl methacrylate (Jung's Historesin - Leica) according to the manufacturer's instructions.

The material embedded in Historesin (Leica HistoresinLeica $^{\mathrm{TM}}$ ) was used to obtain cross-sections of $9-\mu \mathrm{m}$ thickness using a Leica RM2245 rotary microtome. These cross-sections were then subjected to toluidine blue (O'Brien et al. 1964) and were mounted in Vitral Incolor 500 Acrilex ${ }^{\circledR}$ varnish (Paiva et al., 2006). The diaphanized material was placed in $0.1 \%$ aqueous safranin for $24 \mathrm{~h}$, and mounted in hydrated glycerin.

The following characteristics were evaluated: total leaf blade thickness, thickness of palisade parenchyma, thickness of spongy parenchyma, stomatal frequency, stomatal index, diameter of the polar axis of the stomata and diameter of the equatorial axis of the stomata. Four replicates were used per treatment, with each replicate being considered a leaf taken from a plant. To determine thicknesses, 10 sections per leaf were used, while for stomatal analysis 20 quadrants per leaf were used.

\section{Chlorophyll and carotenoid contents}

Samples of $150 \mathrm{mg}$ of leaves of $E$. dysenterica resulting from explants by conventional and natural ventilation systems were taken for the analysis of chlorophyll and carotenoids. The leaves were fragmented and conditioned in 2-mL Eppendorfs microcentrifuges. These were then immersed in $1.5 \mathrm{~mL}$ of acetone, sealed with Parafilm ${ }^{\circledR}$, and maintained in the dark under agitation (100 rpm) for $24 \mathrm{~h}$ at a temperature of $10^{\circ} \mathrm{C}$. The cetonic solution was removed from the tubes and subjected to spectrophotometric reading for the quantification of chlorophyll $a$, chlorophyll $b$ and carotenoids. The calculation of the concentrations of chlorophyll a, chlorophyll $\mathrm{b}$ and carotenoids was performed according to the equations of Lichtenthaler (1987). The experimental design was completely randomized with 2 treatments (two types of lids) and 10 repetitions.

\section{Statistical analysis}

The data were submitted to analysis of variance with a significance level of 5\%. Data analysis was performed using $\mathrm{R}$ software (version 3.4.3) (R Core Team, 2017), while graphics were generated using Graph Pad Prism (version 5.01) (Radushev, 2007).

\section{RESULTS AND DISCUSSION}

\section{Shoot proliferation}

In the conventional system, the best treatment as measured by the variables of height, number of shoots and number of leaves was WPM supplemented with 4.44 $\mu \mathrm{M}$ of BAP with Type 2 buds (means of $42.00 \mathrm{~mm}, 4.33$ shoots and 4.33 leaves, respectively) (Figure 1). In the natural ventilation system, the best result for the variable of height occurred in the treatment of $11.1 \mu \mathrm{M}$ of BAP with Type 2 buds (mean $20.66 \mathrm{~mm}$ ), while for the number of shoots and number of leaves the best treatment was 17.76 $\mu \mathrm{M}$ of BAP with Type 3 buds (means of 6.60 shoots and 9.20 leaves, respectively).

Shoots with lower mean height were reported in the natural ventilation system, compared with the conventional system. In conventional systems, the accumulation of gases such as ethylene occurs within the culture flask. Ethylene can inhibit or promote stem elongation (Suzuki \& Kerbauy, 2006). In this second case, it is promoted by cell division, cell elongation, auxin transport, and auxin action. This occurs, for example, in rice, which showed a greater distance between the internodes when the stem was subjected to ethylene (Abeles et al. 1992; Pierik et al. 2006). Another factor to be considered is the fact that the growth rate of E. dysenterica is considered slow relative to other species (Souza et al., 2002; Silveira et al., 2013). It seems that the plants in flasks of the natural ventilation system probably had a tendency to behave in a manner similar to plants in normal conditions of ex vitro growth; the aerial part of the plants enters a state of latency for at least one year, and only after this period does it begin to grow slowly (Silveira et al., 2013).

Reduced or absent leaves were observed in most of the explants in the conventional system, representing $76.37 \%$ of all the buds inoculated in this group. In contrast, 
only $26 \%$ of the plants in the natural ventilation system did not produce leaves, with an increase of $448.53 \%$ in the number of leaves in relation to the number grown in the conventional system. Cytokinins can cause an increase in ethylene inside the culture flasks in heterotrophic systems (Abeles et al., 1992; Chae, 2003), which can cause decrease on leaf limb, senescence (Pan et al., 2016) and a decrease in chlorophyll production (Silva et al., 2017). Thus, with the increase in gas exchange inside the culture flasks, the accumulation of ethylene likely did not occur, which favored the increase of leaves.

In the present study, shoots coming from intermediate positions (bud type 2 and 3) had higher means in the analyzed variables, in both the conventional system and the natural ventilation system (Figure 1). In shoot proliferation, juvenile explants generally have a better regeneration response under in vitro conditions than to mature explants (Ahuja, 1993). This is probably due to the fact that the highest concentrations of free auxins in plants are found in the apical meristems of the aerial part and in young leaves, therefore forming a gradient of concentration along the stem. (Taiz \& Zeiger, 2010). Thus, the balance between endogenous and exogenous hormones and their interactions, probably contributed to promote positive results in intermediate buds. In addition, in the natural ventilation system with gas
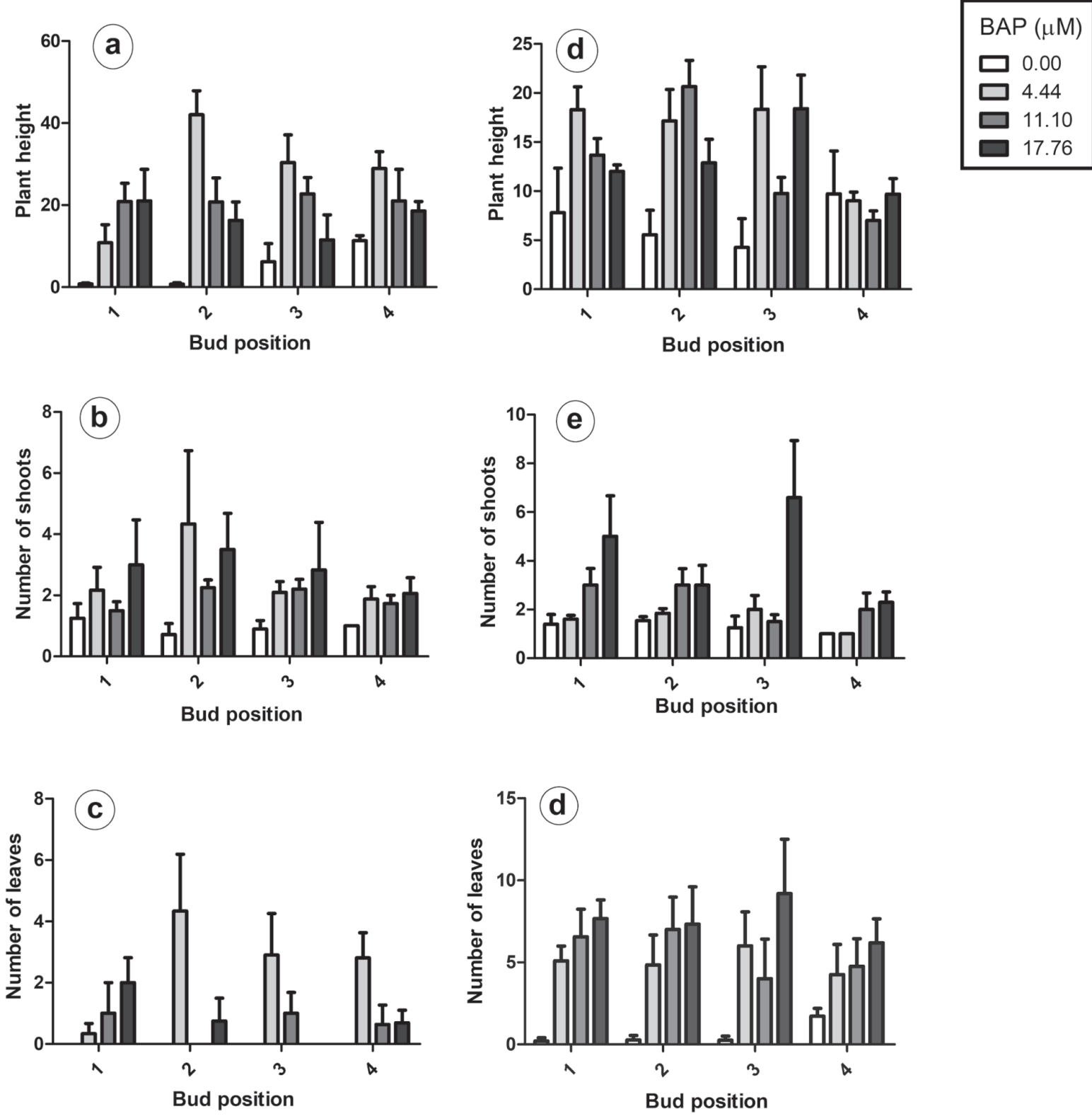

Figure 1: Means for heterotrophic (a, b, and c) and mixotrophic (d, e, and f) systems for four levels of 6-benzylaminopurine (BAP). 1 - Axillary buds proximate to the root; 2 - Axillary buds intermediate between root and caulinar apex; 3 - Axillary buds more proximate to the caulinar apex; 4 - Caulinar apex. Asterisks $\left(^{*}\right)$ indicate significantly different means by the Tukey test at $95 \%$ probability. 
exchange, nutrients and growth regulators were probably better absorbed by the plant because of better transpiration (da Silva et al., 2014). In a study involving guava micropropagation, the bud position influenced the shoot proliferation, leading to intermediate buds with a higher percentage of shoots (Shekafandeh \& KhoshKhui, 2008). Similarly, in another study involving passion- fruit, the authors related that plants with intermediate buds also had higher mean plant height; however, the authors did not observe differences in plant leaf number (Faria et al., 2007). Intermediate buds were superior in a study of Corylus avellana L., in which higher percentages of viability were reported, which consequently increased the proliferation of shoots (Hand et al., 2016).
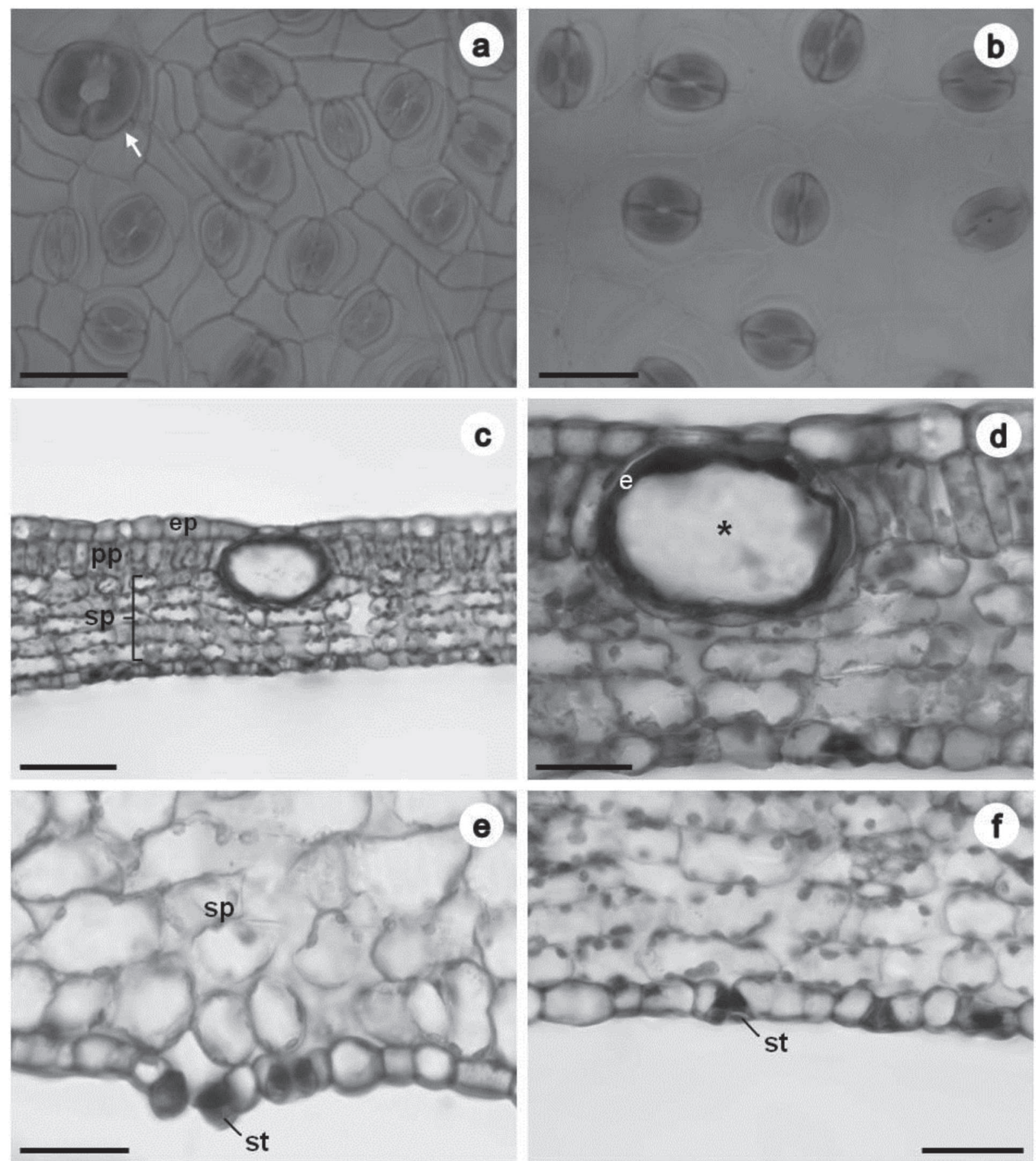

Figure 2: Leaf blade anatomy of Eugenia dysenterica under heterotrophic (a, c and e) and mixotrophic (b, d and f) systems. (a and b frontal view of the abaxial face. c-f transversal section of the internerval region). a and b Stomata on the abaxial face. a "Giant" stomata (arrow). c Dorsiventral mesophyll. d Secretory cavity (asterisk) with uniseriate epithelium. e "Giant" stomata projected above the other epidermal cells. f Stomata at the same level of ordinary epidermal cells. ep - epidermis; pp - palisade parenchyma; sp - spongy parenchyma; e - epithelium; st - stomata. Bars $=50 \mu \mathrm{m}$ ( $\mathrm{a}$ and b, d, e and f); $100 \mu \mathrm{m}$ (c). 


\section{Leaf anatomy}

In both systems, leaves of E. dysenterica had a uniseriate epidermis covered by a thin cuticle and stomata on the abaxial face (Figures. 2a, 2b). Epidermal cells had slightly undulating anticlinal walls (Figures 2a, 2b), on both faces, and dorsiventral mesophyll with a single layer of palisade parenchyma and four to five layers of spongy parenchyma (Figure 2c). Tector trichomes occurred in both treatments. Secretory cavities (Figure 2d) with large lumens and uniseriate epithelium were observed in the mesophyll throughout the extension of the leaf blade.

Eugenia dysenterica cultivated in vitro possesses an organized tissue structure in both evaluated systems. However, plant leaves grown in containers from the conventional system may be thinner and have little differentiated mesophyll (Mohamed \& Alsadon, 2010).

In the conventional system, some larger stomata (Figure 2a), called "giant" stomata were reported, with polar and equatorial diameters of approximately 70 x 55 ìm, respectively. These stomata contained fully opened ostioles and were different from the common stomata, as they projected above the other epidermal cells (Figure $2 \mathrm{e})$. The remaining stomata of this system had mean polar and equatorial diameters of $36 \times 28 \mathrm{im}$. In the natural ventilation system, all stomata were located at the same level as the ordinary epidermal cells (Figure 2f). The occurrence of abnormal stomata in micropropagated plants from heterotrophic systems are reported in some species, such as grapevine (Machado \& Biasi 2011), apple (Chakrabarty et al., 2006) and eucalyptus (Picoli et al., 2008), In these species, these abnormalities are due to hyperhydricity, which causes chemical damage to the cell wall surrounding the stomata orifice, creating cell walls with less callose, that lack the characteristic orientation of cellulose myofibrils (Vasconcelos et al., 2012). Thus, in culture conditions and factors associated with leaf hyperhydration seem to be linked to stomatal malfunction (remaining open) (Ziv \& Ariel, 1994). Junior and Scherwinski-Pereira (2009) reported an increase in the size of the stomata of Tectona grandis L. cultivated in vitro, which may be related to the lack of control in the mechanism of opening and closing of the stomata. Stomata that projected slightly above other epidermal cells were also observed in the leaves of Cymbidium Hort. grown in vitro (Mayer et al., 2008).

The stomatal index and stomatal frequency were greater in the conventional system (Table 1). However, no differences were observed regarding the polar and equatorial diameters of the stomata, or the ratio between the two (Table 1). Additionally, no differences were reported in the thickness of the leaf blade, the palisade parenchyma or the spongy parenchyma (Table 1). For in vitro culture, the decrease in relative humidity with the higher gas exchange in the flask increased the transpiration rate and, consequently, the absorption of water and nutrients by the plant (da Silva et al., 2014). In addition, the high relative humidity inside the culture flask reduces the development of functional stomata, which can lead to losses during acclimatization (Chandra et al., 2010). Further work involving in vitro cultivated $E$. dysenterica hyperhydricity should be developed in the future to confirm the association of abnormal stomata with this condition.

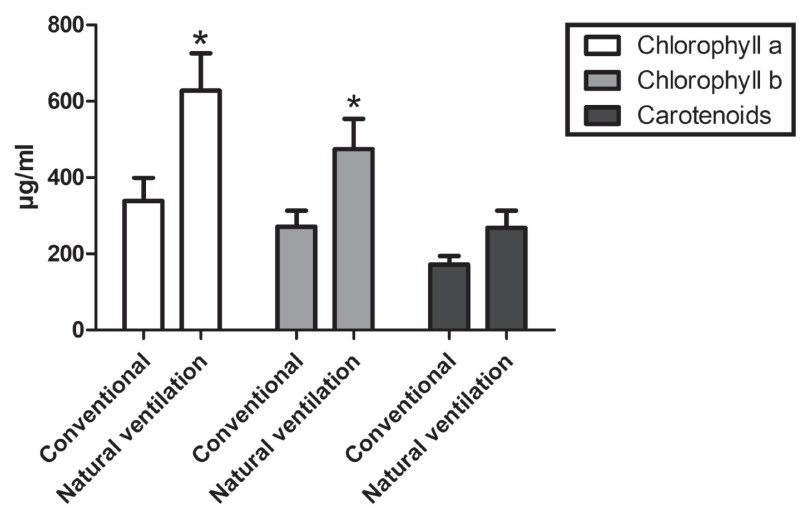

Figure 3: Pigment content from leaves of Eugenia dysenterica under a heterotrophic system and natural ventilation. Asterisks (*) indicate different means (within each group, represented by different colors) by the Tukey test at $95 \%$ probability.

Table 1: Stomata and tissue thickness for the leaf blade of Eugenia dysenterica DC

\begin{tabular}{lcc}
\hline & Conventional system & Natural ventilation system \\
\hline Stomatal frequency $\left(3.3 \mathrm{~mm}^{2}\right)$ & $1054,4 \pm 101.37 \mathrm{a} *$ & $678.4 \pm 51.45 \mathrm{~b}$ \\
Stomatal Index & $38.69 \pm 2.22 \mathrm{a}$ & $31.62 \pm 4.97 \mathrm{~b}$ \\
Stomatal - Polar length - PL $(\mu \mathrm{m})$ & $34.81 \pm 1.99 \mathrm{a}$ & $37.72 \pm 2.75 \mathrm{a}$ \\
Stomatal - Equatorial length $-\mathrm{EL}(\mu \mathrm{m})$ & $28.12 \pm 3.89 \mathrm{a}$ & $28.66 \pm 2.51 \mathrm{a}$ \\
$(\mathrm{PL}) /(\mathrm{EL})$ & $1.26 \pm 0.12 \mathrm{a}$ & $1.33 \pm 0.03 \mathrm{a}$ \\
Leaf blade $(\mu \mathrm{m})$ & $194.07 \pm 17.37 \mathrm{a}$ & $211.97 \pm 20.24 \mathrm{a}$ \\
Palisade parenchyma $(\mu \mathrm{m})$ & $102.65 \pm 10.78 \mathrm{a}$ & $116.22 \pm 15.87 \mathrm{a}$ \\
Spongy parenchyma $(\mu \mathrm{m})$ & $53.78 \pm 6.16 \mathrm{a}$ & $52.80 \pm 3.63 \mathrm{a}$ \\
\hline
\end{tabular}

* Means followed by the same letters (in the row) do not differ from each other according to Tukey's test at $95 \%$ probability. 
Although we report the presence of some abnormal stomata in plants from the conventional system, the high values reported for the ratio between polar diameter and equatorial diameter of the stomata (PD/ED ratio) in the two bottle-sealing conditions indicate functional stomata. According to Rocha (2005), the greater the relationship between $\mathrm{PD}$ and $\mathrm{ED}$, the more ellipsoid the shape of the stomata, and thus the greater its functionality.

In general, a thin cuticle was observed in both culture systems. The cuticle protects the plant against excessive water loss and excess luminosity of solar radiation. However, micropropagated plants in heterotrophic systems usually have an undeveloped cuticle that is related to the high concentration of moisture inside the culture vessel (Johansson et al., 1992).

\section{Chlorophyll and carotenoid contents}

The natural ventilation system promoted an increase of $85.64 \%$ in chlorophyll a levels and $74.90 \%$ in chlorophyll b levels (Figure 3). This can be observed in the leaves of the treatments from the natural ventilation system, which presented intense green coloration (Figure 4).

Stomata play a very important role in regulating the entry and exit of water in plants, as well as the exchange of $\mathrm{CO}^{2}$ (Jones, 1998). Most likely, the pigment

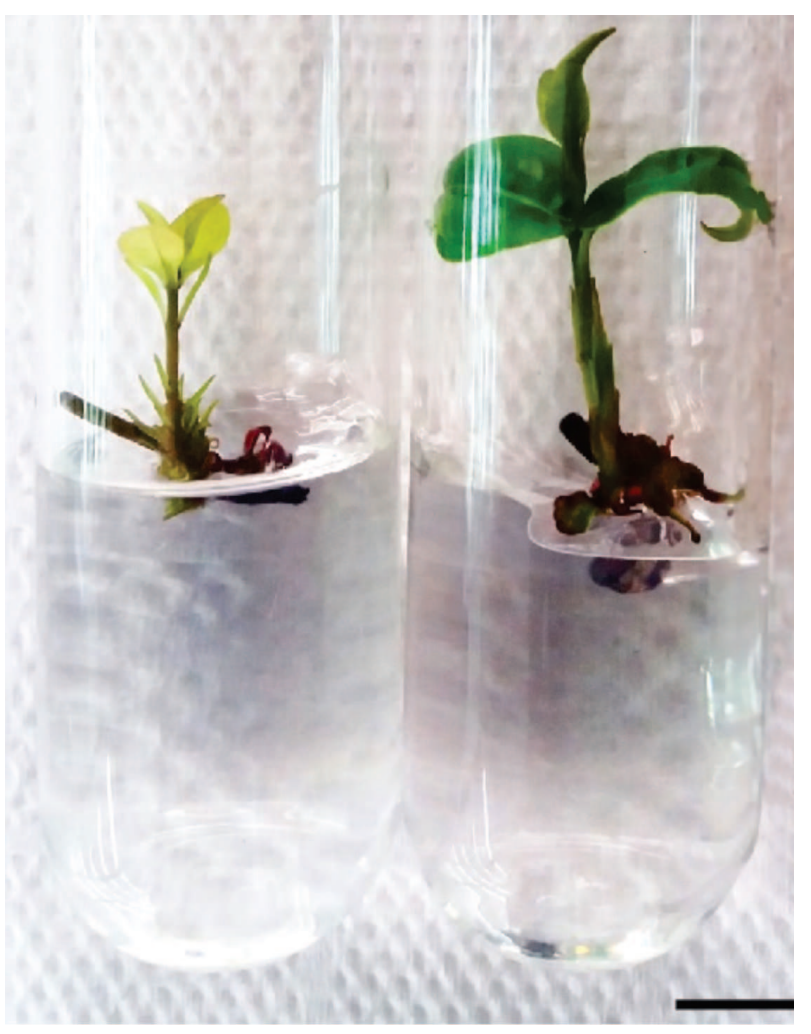

Figure 4: Eugenia dysenterica shoots submitted to treatments with heterotrophic (left) or natural ventilation system (right). Bar $=1 \mathrm{~cm}$. accumulation in plants of the natural ventilation system resulted from a more active photosynthetic machinery as the mixotrophic system allows for $\mathrm{CO}^{2}$ interchanges stimulating photosynthesis (Morison, 1985; Anyia \& Herzog, 2004) Chlorophyll increase was also observed in a strawberry (Fragaria x Ananassa) study using a natural ventilation system, a study in which the authors also reported root growth in plants grown under this system (Pandey et al., 2015). In a study using Pfaffia glomerata (Spreng.), the authors reported that the natural ventilation system pigment synthesis tripled compared to the control, which was reflected in the nutritional quality of the plant (Saldanha et al., 2012). The increase in pigment production was also observed in potato explants submitted to the natural ventilation system, in which a significant increase in explant dry mass was also observed compared to potatoes grown in a conventional system (Mohamed \& Alsadon, 2010).

\section{CONCLUSION}

It is possible to obtain an in vitro shoot proliferation protocol for Eugenia dysenterica with shoots above 20 $\mathrm{mm}$ in height and with a mean number of five leaves per stem. The natural ventilation system is superior at the moment in the formation of new shoots with regard to the number of shoots (greater), number of leaves per shoot (more), chlorophyll production and leaf anatomical characteristics.

The type of bud has an effective influence on micropropagation, with positive responses in plants with buds of intermediate position, regardless of the type of system - conventional or natural ventilation.

The occurrence of a greater number of stomata and the presence of stomata considered "giant" in the plants grown in the conventional system is probably associated with the difficulty of transpiration for these plants due to the high humidity accumulated in the internal environment of the flasks.

Our results indicate that the mixotrophic system can be used in future protocols for rooting E. dysenterica, which will contribute to the maintenance of the genetic resources of this species.

\section{AKNOWLEDGEMENTS, FINANCIAL SUPPORT AND FULL DISCLOSURE}

The authors thank Capes for their financial support in granting a master's degree.

\section{CONFLICT OF INTEREST}

The authors declare that they have no conflict of interest. 


\section{REFERENCES}

Abeles FB, Morgan PW \& Saltiveit ME (1992) Ethylene in plant biology. $2^{\mathrm{a}}$ ed. Boston, Academic Press. 399p.

Ahuja MR (1993) Micropropagation à la carte. In: Ahuja MR (Ed.) Micropropagation of woody plants. Netherlands, Kluwer Academic Publishers. p.03-09.

Andrade ACS, Cunha R, Souza AF, Reis RB \& Almeida KJ (2003) Physiological and morphological aspects of seed viability of a neotropical savannah tree, Eugenia dysenterica DC. Seed Science and Technology, 31:125-137.

Anyia AO \& Herzog H (2004) Water-use efficiency, leaf area and leaf gas exchange of cowpeas under mid-season drought. European Journal of Agronomy, 20:327-339.

Baker NR (2008) Chlorophyll Fluorescence: A Probe of Photosynthesis In Vivo. Annual Reviews of Plant Biology, 59:89-113.

Brandão RJA, Castilho CJM \& Morais HA (2017) Modern agriculture in the Cerrado Biome: continuing the disrespect of nature. Jounal of Hyperspectral Remote Sensing, 7:134-149.

Camilo Y, Souza E, Vera R \& Naves R (2013) Fenologia, produção e precocidade de plantas de Eugenia dysenterica visando melhoramento genético. Revista de Ciências Agrárias, 36:192-198.

Chae HS (2003) The eto1, eto2, and eto3 Mutations and Cytokinin Treatment Increase Ethylene Biosynthesis in Arabidopsis by Increasing the Stability of ACS Protein. The Plant Cell, 15:545-59.

Chakrabarty D, Park SY, Ali MB, Shin KS \& Paek KY (2006) Hyperhydricity in apple: Ultrastuctural and physiological aspects. Tree Physiology, 26:377-388.

Chandra S, Bandopadhyay R, Kumar V \& Chandra R (2010) Acclimatization of tissue cultured plantlets: From laboratory to land. Biotechnology Letters, 32:1199-1205.

da Silva AB, Lima PP, de Oliveira LES \& Moreira AL (2014) In vitro growth and leaf anatomy of Cattleya walkeriana (Gardner, 1839) grown in natural ventilation system. Revista Ceres, 61:883-890.

da Silva MMM, da Silva EP, da Silva FA, Ogando FIB, de Aguiar CL \& Damiani C (2017) Physiological development of cagaita (Eugenia dysenterica). Food Chemistry, 217:74-80.

Dias PC, Oliveira LS de, Xavier A \& Wendling I (2012) Estaquia e miniestaquia de espécies florestais lenhosas do Brasil. Pesquisa Florestal Brasileira, 32:453-462.

Duarte EFEA (2006) Germinação e vigor de sementes de cagaita (Eugenia dysenterica MART. ex DC.) em função de seu tamanho e tipo de coleta. Pesquisa Agropecuária Tropical, 36:173-179.

Faria GA, Costa MAPC, Ledo CAS, Junghans TG, Souza AS \& da Cunha MAP (2007) Meio de cultura e tipo de explante no estabelecimento in vitro de espécies de maracujazeiro. Bragantia, 66:535-543.

Farias Neto AL, Fonseca CEL, Gomide CCC \& Silva AJ (1991) Armazenamento de sementes de cagaita. Revista Brasileira de Fruticultura, 13:55-62.

Gago J, Daloso D de M, Figueroa CM, Flexas J, Fernie AR \& Nikoloski Z (2016) Relationships of Leaf Net Photosynthesis, Stomatal Conductance, and Mesophyll Conductance to Primary Metabolism: A Multispecies Meta-Analysis Approach. Plant Physiology, 171:265-279.

Galheigo MRU, Prado LC da S, Mundin AMM, Gomes DO, Chang R, Lima AMC, Canabrava HAN \& Bispo-da-Silva LB (2016) Antidiarrhoeic effect of Eugenia dysenterica DC (Myrtaceae) leaf essential oil. Natural Product Research, 30:1182-1185.
Hand CR, Wada N, Stockwell V \& Reed BM (2016) Node position influences viability and contamination in hazelnut shoot explants. In Vitro Cell and Developmental Biology - Plants, 52:580-589.

Hawkes JG, Maxted N \& Ford-Lloyd BV (2012) The ex situ conservation of plant genetic resources. $1^{\mathrm{a}}$ ed. Birmingham, Springer Science \& Business Media. 249p.

Hazarika BN (2006) Morpho-physiological disorders in in vitro culture of plants. Scientia Horticulturae, 108:105-120.

Johansen DA (1940) Plant microtechnique. $1^{\text {a }}$ ed. London, McGraw-Hill Book Company. 530p.

Johansson M, Kronestedt-Robards EC \& Robards AW (1992) Rose leaf structure in relation to different stages of micropropagation. Protoplasma, 166:165-176.

Jones HG (1998) Stomatal control of photosynthesis and transpiration. Journal of Experimental Botany, 49:387-398.

Junior PCPF \& Scherwinski-Pereira JE (2009) Anatomical characteristics of leaves from Teak (Tectona grandis L.f.) developed under in vitro and ex vitro culture conditions. Evidência - Ciência e Biotecnologia, 9:17-28.

Kozai T \& Kubota C (2001) Developing a Photoautotrophic Micropropagation System for Woody Plants. Journal of Plant Research, 114:525-537

Kozai T \& Kubota C (2005) Concepts, definitions, ventilation methods, advantages and disavantages. In: Kozai T, Afreen F \& Zobayed SMA (Eds.) Photoautotrophic (Sugar-free Medium Micropropagation as a new micropropagation and transplant Product system. Dordrecht, Springer. p.19-23.

Lichtenthaler HK (1987) Chlorophylls and carotenoids: Pigments of photosynthetic biomembranes. Methods of Enzymology, 148:350-382.

Lima TB, Silva ON, Oliveira CJTA, Vasconcelos IM, Scalabrin FB, Rocha TL, Grossi-de-Sá MF, Silva LP, Guadagnin RV \& Quirino BF (2010) Identification of E. dysenterica laxative peptide: A novel strategy in the treatment of chronic constipation and irritable bowel syndrome. Peptides, 31:14261433.

Lima TB, Silva ON, Silva LP, Rocha TL, Grossi-de-Sá MF, Franco OL \& Leonardecz E (2011) In Vivo Effects of Cagaita (Eugenia dysenterica, DC.) Leaf Extracts on Diarrhea Treatment. Evidence-Based Complementary and Alternative Medicine, 2011:01-10

Lloyd GB \& McCown BH (1980) Commercially-feasible micropropagation of Mountain laurel, Kalmia latifolia, by use of shoot tip culture. International Plant Propagation Society, 30:421-426.

Machado MP \& Biasi LA (2011) Morfoanatomia das folhas do porta-enxerto de videira 'VR043-43' (Vitis vinifera $\mathrm{L} . \times$ Vitis rotundifolia michx.) em diferentes condições de cultivo. Revista Acadêmica Ciências agrárias e Ambiente, 9:73-78.

Martinotto C, Paiva R, Santos BR, Soares FP, Nogueira RC \& Silva ÁAN (2007) Effect of scarification and light on in vitro seed germination of (Eugenia dysenterica DC.). Ciência e agrotecnologia, 31:1668-1671.

Mayer JLS, Ribas LLF, Bona C \& Quoirin M (2008) Anatomia comparada das folhas e raízes de Cybidium Hort. (Orchidaceae) cultivadas ex vitro e in vitro. Acta botanica brasileira, 22:323332 .

Mohamed MAH \& Alsadon AA (2010) Influence of ventilation and sucrose on growth and leaf anatomy of micropropagated potato plantlets. Scientia Horticulturae, 123:295-300. 
Monja-Mio KM, Pool FB, Herrera GH, EsquedaValle M \& Robert ML (2015) Development of the stomatal complex and leaf surface of Agave angustifolia Haw. "Bacanora" plantlets during the in vitro to ex vitro transition process. Scientia Horticulturae, 189:32-40.

Morison JIL (1985) Sensitivity of stomata and water use efficiency to high CO2. Plant Cell Environment, 8:467-474.

O'Brien TP, Feder N \& McCully ME (1964) Polychromatic staining of plant cell walls by toluidine blue O. Protoplasma, 59:368-373.

Paiva JGA De, Fank-de-Carvalho SM, Magalhães MP \& GracianoRibeiro D (2006) Verniz vitral incolor 500®: uma alternativa de meio de montagem economicamente viável. Acta Botanica Brasilica, 20:257-264

Pan Y-J, Liu L, Lin Y-C, Zu Y-G, Li L-P \& Tang Z-H (2016) Ethylene Antagonizes Salt-Induced Growth Retardation and Cell Death Process via Transcriptional Controlling of Ethylene-, BAG- and Senescence-Associated Genes in Arabidopsis. Frontiers in Plant Science, 19:696.

Pandey S, Singh J, Singh SK \& Mourya IB (2015) Influence of growing environment on growth, yield and chemical composition of strawberry (Fragaria $\times$ ananassa) fruits under open vs naturally ventilated polyhouse conditions. Indian Journal of Agriculture Science, 85:1540-1545.

Picoli EAT, Paiva EAS, Xavier A, Aguiar RM, Carolino SMB, Fári MG \& Otoni WC (2008) Ultrastructural and biochemical aspects of normal and hyperhydric eucalypt. International Jounal of Horticulturae Science, 14:61-69.

Pierik R, Tholen D, Poorter H, Visser EJW \& Voesenek LACJ (2006) The Janus face of ethylene: growth inhibition and stimulation. Trends in Plant Science, 11:176-183.

$\mathrm{R}$ development Core Team (2017) R: A language and environment for statistical computing. Vienna, R Foundation for Statistical Computing. Available at: <http://www.R-project.org>. Accessed on: February $3^{\text {rd }}, 2018$.

Radushev D (2007) GraphPad Prism. Version 5. GraphPad Software. Available at: <https://graphpad-prism.software.informer.com/ 5.0/>. Accessed on: August $23^{\text {rd }}, 2019$.

Rocha HS (2005) Luz e sacarose na micropropagação da bananeira "Prata Anã": alterações morfoanatômicas. Dissertação de mestrado. Universidade Federal de Lavras, Lavras. 98p.

Saldanha CW, Otoni CG, de Azevedo JLF, Dias LLC, do Rêgo MM \& Otoni WC (2012) A low-cost alternative membrane system that promotes growth in nodal cultures of Brazilian ginseng [Pfaffia glomerata (Spreng.) Pedersen]. Plant Cell Tissue and Organ Culture, 110:413-422.
Shekafandeh A \& Khosh-Khui M (2008) Effects of bud position and culture medium on shoot proliferation from nodal culture of two mature guava cultivars. Asian Jounal of Plant Science, $7: 177-182$.

Silva SMM, Silva CAG, Fonseca-Bazzo YM, Magalhães PO \& Silveira D (2015) Eugenia dysenterica Mart. Ex DC. (cagaita): planta brasileira com potencial terapêutico. Infarma Ciências Farmaceuticas, 27:49-95

Silva ST, Bertolucci SKV, Cunha SHB da, Lazzarini LES, Tavares MC \& Pinto JEBP (2017) Effect of light and natural ventilation systems on the growth parameters and carvacrol content in the in vitro cultures of Plectranthus amboinicus (Lour.) Spreng. Plant Cell, Tissue and Organ Culture, 129:501-510.

Silveira CES, Palhares D, Pereira LAR, Pereira KBD \& Silva FAB (2013) Strategies of plant establishment of two Cerrado species: Byrsonima basiloba Juss. (Malpighiaceae) and Eugenia dysenterica Mart. ex DC (Myrtaceae). Plant Species Biology, 28:130-137.

Souza ERB De, Naves RV, Carneiro IF, Leandro WM \& Borges JD (2002) Growth and survival of cagaita (Eugenia dysenterica DC) plants in tropical savanas. Revista Brasileira de Fruticultura, 24:491-495.

Souza PM, Elias ST, Simeoni LA, de Paula JE, Gomes SM, Guerra ENS, Fonseca YM, Silva EC, Silveira D \& Magalhães PO (2012) Plants from Brazilian Cerrado with Potent Tyrosinase Inhibitory Activity. PLoS One, 7:e48589.

Suzuki RM \& Kerbauy GB (2006) Effects of light and ethylene on endogenous hormones and development of Catasetum fimbriatum (Orchidaceae). Brazilian Jounal of Plant Physiology, 18:359-365.

Taiz L \& Zeiger E (2010) Fisiologia Vegetal. 5a ed. Porto Alegre, Artmed. 782p.

Takao LK, Imatomi M \& Gualtieri SCJ (2015) Antioxidant activity and phenolic content of leaf infusions of Myrtaceae species from Cerrado (Brazilian savanna). Brazilian Jounal of Biology, 75:948-952.

Vasconcelos AGV de, Tomas LF, Camara TR \& Willadino L (2012) Hiperidricidade: uma desordem metabólica. Ciência Rural, 42:837-844.

Ziv M \& Ariel T (1994) Vitrification in relation to stomatal deformation and malfunction in carnation leaves in vitro. In: Lumsden PJ, Nicholas JR \& Davies WJ (Ed.) Physiology, Growth and Development of Plants in Culture. Dordrecht, Springer. p.142-154. 